\title{
Development of infrastructure funds for the mobilization of private capital for of the infrastructure projects implementation
}

\author{
Salima Makhosheva ${ }^{1}$, Irina Polyakova ${ }^{2, *}$, and Igor Merzlikin ${ }^{3}$ \\ ${ }^{1}$ Institute of Informatics and Problems of Regional Management, Branch of Federal Scientific Center, \\ Kabardino-Balkarian Scientific Center, RAS, 37a I. Armand Str., Nalchik, Russia, 360004 \\ ${ }^{2}$ Moscow State University of Civil Engineering, 26 Yaroslavskoye sh., Moscow, Russian Federation, \\ 129337
}

${ }^{3}$ Moscow State Technical University of Civil Aviation, 20 Kronshtadtsky blvd, Moscow, 125993, Russia

\begin{abstract}
The purpose of this work is to prove the expediency and efficiency of the development of infrastructure funds for the attraction of private equity for the infrastructure projects implementation. Statistics, readiness of institutional investors to invest money in infrastructure, the key risks which exist in the country in this sphere are studied by the authors. The need for the reliable professional partner who could be presented by infrastructure funds is revealed. The authors consider the benefits of infrastructure funds for the attraction of capitals from private investors, for providing them with guarantees and for the increase in their activity in the market. As the predictable result the infrastructure funds are capable to provide missing financing for the development of infrastructure of the country, regions, municipal units. The conclusions received by the authors within their research can be used when developing economic policy of the country, when developing investment policy and the strategy of the country, when developing development programs of infrastructure of regions of the Russian Federation, the certain cities and regions of the country.
\end{abstract}

\section{Introduction}

Nowadays the need for private investments into national infrastructure projects in Russia makes up 7.5 trillion roubles until the end of 2024. This figure represents the necessary minimum for Russia, but the needs for the development of infrastructure in the country are much broader, than only the purposes of several national projects. If one tries to estimate the regional and municipal needs for modernization and creation of infrastructure in details, then the figure will be much more. It is necessary to aim about $10-15 \%$ of gain of the financial sector for its development to satisfy demand in financing of infrastructure in Russia. That means not $10-15 \%$ of the whole sector, but the share of the gain literary. Thus, from the point of view of the organization of management this task is not impracticable.

\footnotetext{
*Corresponding author: elena.chibisova_metr@mail.ru
} 
But in Russia of today banks are the only type of investors who can actively act on the market of infrastructure investments.

The pension funds and insurance companies have no potential to become the leading players of the market of infrastructure financing in Russia as they face too many restrictions.

For comparison the foreign pension funds, lead up the amount of funds, allocated for financing of infrastructure up to $5 \%$ of the volume of the assets, the most courageous allocate up to $20 \%$ of the assets. Taking into account the size of means under the control of the pension funds and insurance companies in Russia, such share of the volumes of the pension funds and insurance companies will not be able to change situation globally. That means that it is necessary to place the emphasis on work with banks from the point of view of the organization of activity, and in terms of other financing sources it is necessary to search a new creative mechanisms in order to make money flow from old industries into the new directions of the economy development.

The creation of infrastructure funds is capable to become such a mechanism.

The matters of financing of infrastructure are considered in the works by O.M. Vasilyev, M. Kopeykin, B.Kh. Krasnopolsky, V.N. Livshits, N.A. Nesterov, S.S. Nosova, B.A. Solovyov, N.T. Toshchenko, I.F. Chernyakhovsky, Yu.G. Yudin's works. Certain contribution to the development of the theory of infrastructure was made by A.I. Kocherga, A.A. Mazaraki, V.I. Karsekin, S.I. Tyulpanov, V. Zhamin, S.I. Hvatov, T. Semenkova. It is also necessary to name F.A. Krutikov, A.I. Levin, B.E. Manevich, P.P. Maslov, V.K. Nefedov, A.V. Orlov, B.A. Solovyov, R.I. Shniper, V.V. Shvyrkov, etc. The need of forming of new approaches to forming of methodology of infrastructure are connected with the research works by E.G. Kochetov, A.I. Neklessa, M.A. Pivovarova, I.G. Vladimirova and others $[1,2,3,4,5]$.

However, the carried-out work is not enough. The current state of the infrastructure sphere demands attraction of the huge capital investments for its development, and infrastructure funds are capable to become the new progressive instrument of mobilization of the capital. However, this topic is insufficiently covered in scientific literature that does our research relevant.

\section{Materials and Methods}

The research was carried out with the use of scientific methods of the analysis and synthesis, classification, mathematical statistics, economic analysis, mathematical modeling.

The materials for the research include the economic facts established on the basis of these statistical and financial and economic publications in Russia and other countries, data from Internet, materials of scientific seminars and conferences, statistical data of Goskomstat of the Russian Federation, data of the "New Economic Growth" agency, Russian Government Analytical Centre, National agency of financial studies.

\section{Results and Discussion}

Though the infrastructure of Russia does not receive enough financing, our research showed the following:

- $63 \%$ of institutional investors consider the possibility of increase in investments into infrastructure

$-47 \%$ of institutional investors are going to increase their investments in infrastructure within the next five years 
- 38\% of institutional investors are ready to consider investments for the term of 10 years and more.

Respondents also listed the key risks, interfering the growth of their activity in the sphere of investments into infrastructure [6, 7] (Fig. 1).

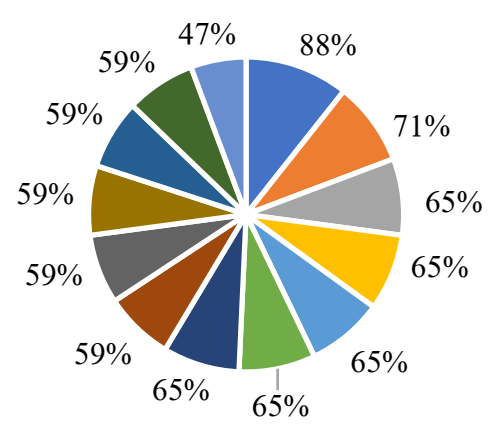

- Regional or municipal policy risk

- Risk of the construction delay

- Complexity of the the infrastructure projects analysis

- Long procedure of contracting

- Risk of errors of long-term demand for services

- Risk of errors of design

- Risk of tariff regulation

- Risk of non-execution of the obligations by the public partner

- Risk of rendering low-quality services

- Risk of the construction cost management

- Risk of operating costs management

- Limited choice of the investment opportunities

- Reliability and quality of contractors and operators

Fig. 1. Key risks of investments into infrastructure according to the Russian institutional investors (\% of respondents).

At the same time $67 \%$ of institutional investors need a professional partner for the development of their investment activities for the sake of the infrastructure development. Such a partner should have the following features:

- Experience in structuring and analysis of infrastructure projects

- Own pipeline of the project opportunities

- Capability to bear risks of business development within joint investment policy

- Experience of management of the infrastructure companies and projects

- Capability to co-invest and bear risks of participation in the project

- Experience of presence in security market

- Capability to mobilize political support to projects

- Capability to mobilize financial support of the project.

At such a conjuncture the growth of financing of infrastructure can be provided with the attraction of financial institutions of the average size within the collective organization of investment activities by the means of creation and development of infrastructure funds.

Infrastructure funds occupy already more than $2 \%$ in the general structure of investment funds in the world. For the last decade the number of funds has grown actually from 0 to more than 700. Dynamics of the attraction has a rising trend. In 2018 the infrastructure 
funds attracted the record amount of funds of $\$ 103.6$ billion, in the first half of 2019 they attracted 41.4 billion $\$$ [8, 9, Ошибка! Источник ссылки не найден.].

Figure 2 presents the dynamics of attraction of financial resources by the infrastructure funds.

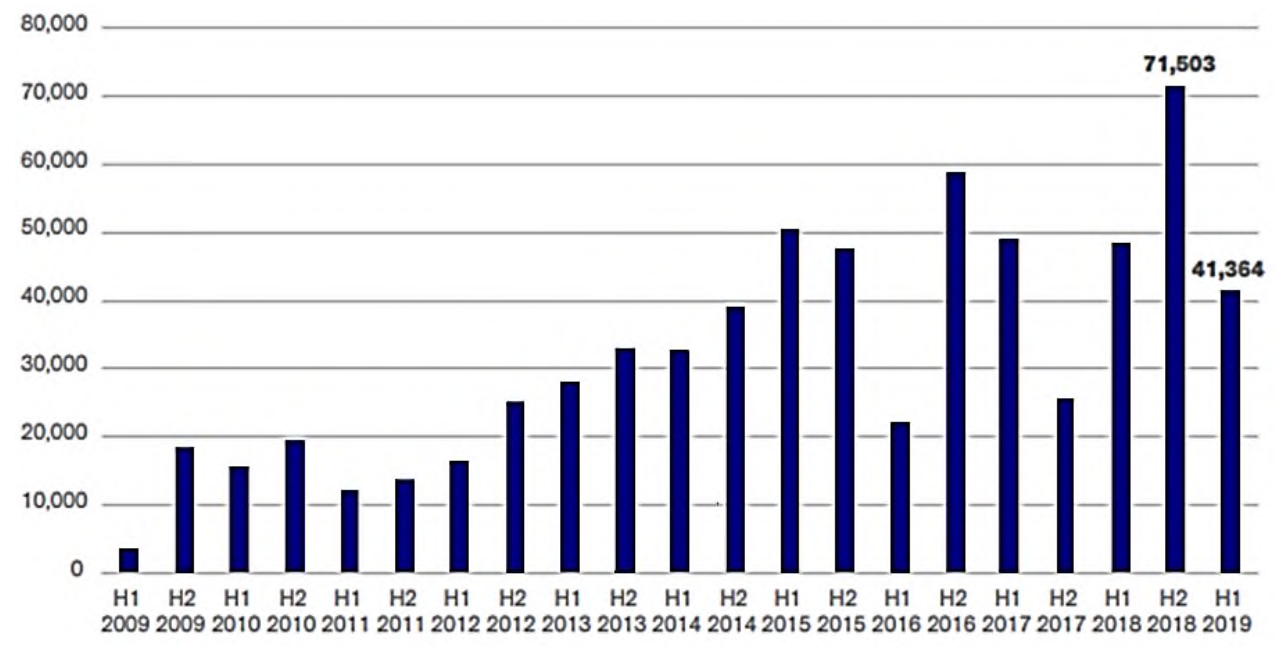

Fig. 2. Volume of the funds raised by infrastructure funds, $\$ \mathrm{mln}$.

Pension and sovereign funds, insurance companies act as the biggest strategic investors of infrastructure funds.

Infrastructure funds along with organized financial markets will be able mainly to deal with project investments in which characteristics of new asset class are formed.

The organization of funds allows:

1. Forming of specialized examination and pipeline of projects at the expense of partners of managing company,

2. Allocation of costs on the use of specialized examination of managing company on all the participating investors and on project portfolio of Fund. The average size of charges of division on financing of infrastructure in the leading organizations about 300 million rubles a year,

3. Distribution of risk of a default of the separate project on the whole investment portfolio of the fund. Lower risk of default on investment portfolio, than on the project, exists in case of sufficient diversification $[10,12,13]$,

4. Achievement of barrier to entry in projects at the expense of the size of the fund formed by several participants.

The approximate size of fund is from 25 billion rubles. The average extent of the most widespread category of infrastructure projects (such as regional highways) is 10-20 billion rubles. Target share of fund in project financing - 0.5-3 billion rubles. The minimum diversification providing distribution of risk is supposed at a rate of 15-20 projects.

The analysis of available data shows that risks of loans of project financing approach investment quality in 5-7 years of the project (Fig. 2). 


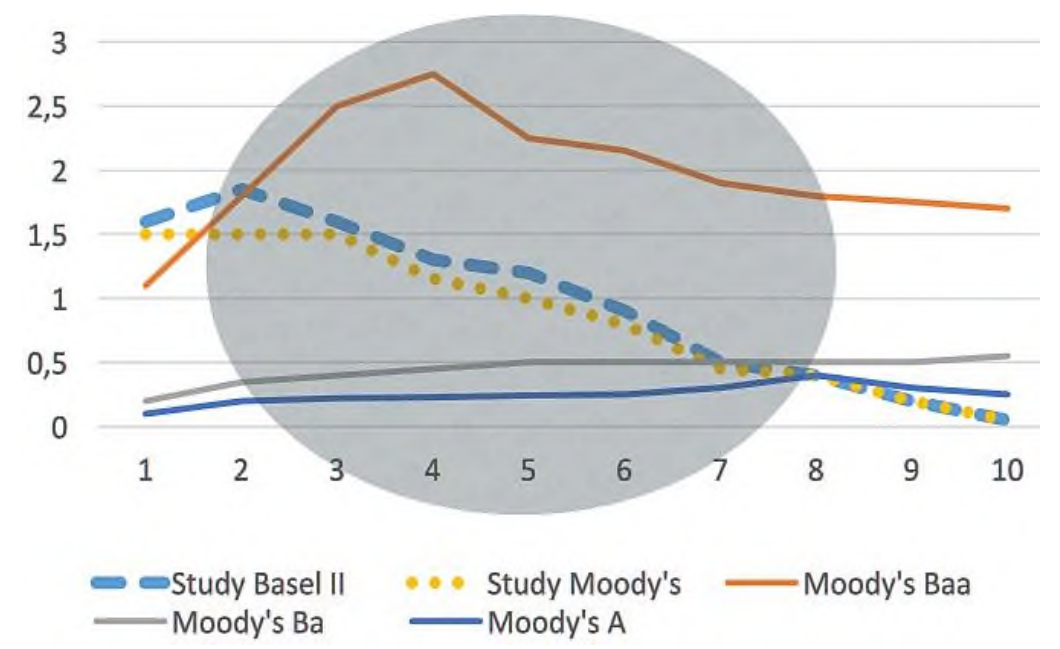

Fig. 3. Dynamics of the probability of a default of loans of project financing (\%) during the project in comparison with corporate bonds of various credit risk [Ошибка! Источник ссылки не найден., 14].

Such results owe life attractive to the private partner.

However, the mechanism of mutual investment funds is not deprived of shortcomings from the point of view of the private investor:

- The analytical section of the fund has to choose the most profitable shares, real estate and others subject for investment. But, not all the specialists in the fund really understand the issues at the financial markets, so that they can choose not the most productive tools. Therefore, not all the funds are profitable, but irrespective of the income of investors, the fund receives the commission. This disadvantage could be overcome by the professional development of personnel of the fund [15].

- As the key purpose of mutual fund is profit, it is logical that each share has costs and risks. One should not forget that the mutual investment fund consists of different articles of wastes in addition to the commission.

- It is possible to see how the growth of the price of share fraction falls at the expense of other assets in mutual fund. Decline of the total price of assets because of diversification is probable succession of events. As management of fund puts for the purpose not to merge the capital, significant increase in specific securities not too is evident as in portfolio there are a lot of different assets.

- The profit from mutual funds is always assessed with tax. In certain situations, it is simpler to offer share for sale, than to receive profit from fund.

To give to investors the chance to reasonably choose fund for partnership, it is necessary to make the ratings of funds.

In Russia there are no specialized infrastructure private equity funds because of the immaturity of the market. Meanwhile, according to the foreign experience, such funds are interested to participate in projects at operation stage due to the lack of the risks inherent in preparatory and investment stages. But in Russia there is no market of projects at this stage. The available projects raise questions of the quality. The only private equity fund which is actually operating in the Russian infrastructure market should participate in projects of PPP prior to construction. Considering the features of the market of projects of PPP $[16,17,18]$, it also finances other projects, including industrial, commercial real estate, etc.

It is possible to allocate the following problems of the specialized infrastructure private equity funds development in Russia [19-23]: 
- low joint-stock yield at high risks of investments,

- high transaction costs,

- the small number of qualitative projects for entrance (very strict requirements to projects result in lack of subjects for investment, rather liberal lead to increase in risks),

- absence of investment-and-construction-and-operating companies in the market, low interest in this tool from the point of view of the acting active market participants.

Thus, despite the demand of infrastructure funds in our country, this mechanism still needs careful completion and control from the state.

\section{Conclusions}

The Russian infrastructure market needs serious updating. In order to make private equity to be put to this market effectively, various tools and methods of mobilization of the capital are necessary.

Infrastructure funds solve some problems:

- make possible the examination of the leading infrastructure funds includes not only the experience of implementation of transactions on acquisition of the relevant companies, but also on their development and management, including all the difficult industrial and technology aspects of the projects,

- allow to solve problem of excessive focusing of the pension funds and managing companies on short-term yield,

- allow funds both to diversify and to balance the portfolios at the same time,

- allow to expand the circle of investors, as according to the world practice, only the largest institutional investors have the opportunity to finance infrastructure projects directly.

The creation of the favorable environment for the funds in the market of infrastructure investments will allow to increase its attractiveness for more wide range of investors.

\section{Acknowledgements}

The reported study was funded by RFBR, project number 20-010-00863.

\section{References}

1. Clarkson Research, UN Comtrade, ISSA, Trade Data Analytics and Visualization (McKinsey\&Company, 2018) https://www.mckinsey.com/businessfunctions/mckinsey-analytics/our-insights

2. H.T. Phuong, E. Scherbina, Basic research 7, 373-378 (2019)

3. V. Carbone, Maritime Policy \& Management 30(4), 305-320 (2003)

4. N. Evreenova, World of Transport and Transportation 5, 170-176 (2014)

5. P.B. Richman, Private Investments (2007)

DOI: 10.1097/01.EEM.0000298839.52903.d5

6. The expert collection Infrastructure funds as the mechanism of mobilization of private equity for implementation of national projects in the Russian Federation: requirements, prospects, barriers (Moscow, 2019)

7. Public Private Infrastructure Advisory Facility, The State of Infrastructure PublicPrivate Partnerships in Countries Affected by Fragility, Conflict or Weak Institutions (USA, Washington, 2018) 
8. Y.M. Bandara, Hong-Oanh Nguyen, S.-L. Chen, Asian Journal of Shipping and Logistics 29(2), 187-206 (2019)

9. P.C. Millán, J. Baños-Pino, I. Mateo-Mantecón, Essays on Port Economics. The Effect of Port Infrastructures on Regional Production (Springer, 2010)

10. E. Anoshkina, E. Markovskaya, A. Mottaeva, As. Mottaeva, E3S Web of Conferences 210, 13022 (2020) https://doi.org/10.1051/e3sconf/202021013022

11. E.Yu. Vasilieva, Russian economic online journal 3 (2019) www.erej.ru/Articles/2019/Vasilieva.pdf

12. E. Vasilyeva, Y. Krupnov, E3S Web of Conferences 164, 10037 (2020)

13. A. Zhundrikov, E. Galaktionova, J. Yakunina, J. Dordzhiyeva, Infrastructure of Russia: index of development (INFRAOne Research, Saint-Petersburg, 2018)

14. A.V. Bataev, A.A. Gorovoy, A.B. Mottaeva, Proceedings of the 32nd International Business Information Management Association Conference, IBIMA 2018 - Vision 2020, 88-101 (2018)

15. M. Byrne, H. Sipsas, T. Thompson, International Advances in Economic Research 2(4), 471-476(1996)

16. A. Polyakova, E. Vasilyeva, IOP Conference Series Earth and Environmental Science 90(1), 012121 (2017)

17. A. Polyakova, E. Vasilyeva, N. Vorontsova, IOP Conference Series Earth and Environmental Science 90(1), 012136 (2017)

18. K. Stamatović, P.W. De Langen, A. Groznik, Research in Transportation Business and Management (2018) DOI: 10.1016/j.rtbm.2018.03.006

19. F. Nistor, C. Popa, R. Gavra, Scientific Bulletin of Naval Academy XXI, 163-167 (2018)

20. A. Mottaeva, MATEC Web of Conferences 106, 08071 (2017)

21. C. Woudsma et al., Transportation Research Procedia 12, 474-488 (2016)

22. E. Ganebnykh, T. Burtseva, N. Mironova, O. Feoktistova, E3S Web of Conferences 110, 01077 (2019)

23. O.N. Soboleva, T.A. Burtseva, E.A. Barmina, E.V. Ganebnykh, P.V. Tokareva, Contribution to Economics, 565-574 (2017) DOI: 10.1007/978-3-319-60696-5_71 